ORNL/Sub/95-SU604/03

\title{
Evaluation of Iron Aluminide Weld Overlays for Erosion-Corrosion Resistant Boiler Tube Coatings in Low NOx Boilers
}

\author{
April 28, 2000 \\ Report Prepared by \\ J.R. Regina, M. Lim, N. Barbosa, J.N. DuPont, and A.R. Marder \\ Lehigh University \\ Energy Research Center \\ 117 ATLSS Drive \\ Bethlehem, PA 18015-4729 \\ under \\ 19X-SU604V
}

for

OAK RIDGE NATIONAL LABORATORY

Oak Ridge, Tennessee 37831

Managed by

UT-BATTELLE, LLC

for the

U.S. DEPARTMENT OF ENERGY

under contract DE-AC05-00OR22725 

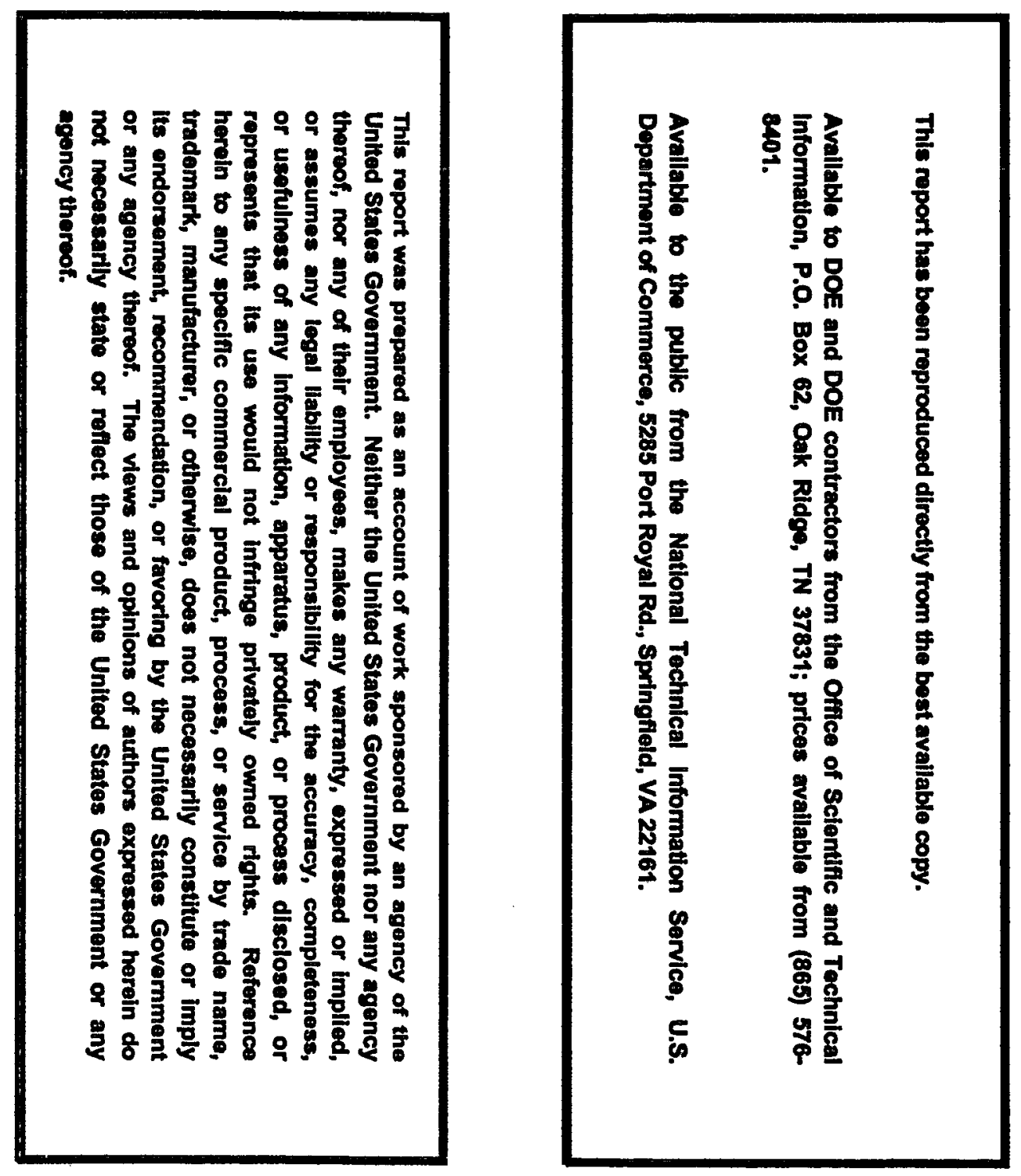


\section{DISCLAIMER}

Portions of this document may be illegible in electronic image products. Images are produced from the best available original document. 
Evaluation of Iron Aluminide Weld Overlays for Erosion-Corrosion Resistant Boiler Tube Coatings in Low NOx Boilers

April 28, 2000

Research Sponsored by the U.S. Department of Energy, Office of Fossil Energy

Advanced Research Materials Program

Report Prepared by

J.R. Regina, M. Lim, N. Barbosa, J.N. DuPont, and A.R. Marder

Lehigh University

Energy Research Center

117 ATLSS Drive

Bethlehem, PA 18015-4729

under

19X-SU604V

for

OAK RIDGE NATIONAL LABORATORY

Oak Ridge, Tennessee 37831

Managed by

UT-BATTELLE, LLC

for the

U.S. DEPARTMENT OF ENERGY

under contract DE-AC05-00OR22725 


\subsection{EXECUTIVE SUMMARY}

Iron aluminide weld overlays containing ternary additions and thermal spray coatings are being investigated for corrosion protection of boiler tubes in Low NOx burners. The primary objective of the research is to identify overlay and thermal spray compositions that provide corrosion protection of waterwall boiler tubes. In the current phase of work, preliminary corrosion tests were conducted on a binary $\mathrm{Fe}-\mathrm{Al}$ alloy in multiple complex gases to determine which gases will be used for testing of the ternary alloys. Preliminary solid-state corrosion tests were also conducted to simulate slag-metal interactions seen in Low NOx furnaces. Two powder compositions were chosen for testing of the ternary alloys. A matrix of alloys to be tested in both gaseous and solidstate corrosion experiments was produced based on corrosion literature.

Research sponsored by the U.S. Department of Energy, Fossil Energy Advanced Research Materials Program, DOE/FE AA 151010 0, Work Breakdown Structure Element $L U-2$. 


\subsection{INTRODUCTION}

Recent clean air regulations have required electric power companies to decrease NOx emissions, which has led to a reducing/sulfidizing environment within the boiler. Because of these new boiler conditions, protective oxide scales traditionally formed on the low alloy $\mathrm{Cr}$-Mo steel boiler tubes are now being replaced by less protective sulfide scales $^{1}$. These sulfide scales are causing unacceptable waterwall wastage rates, which have led to costly forced outages. Therefore, to reduce the corrosion of the boiler tubes, new materials are being considered as corrosion resistant coatings ${ }^{2}$.

Iron-aluminides are among the systems being considered as coatings. Ironaluminum alloys have demonstrated excellent corrosion resistance in high-temperature reducing environments ${ }^{3-6}$. Iron-aluminum alloys are unsuitable for structural applications as they show a sharp drop in strength above $600^{\circ} \mathrm{C}$ and have low room temperature ductility $^{2}$. Fortunately, recent work has shown that they possess good weldability up to $10 \mathrm{wt} \% \mathrm{Al}^{7}$. Their good weldability coupled with the fact that they are less expensive than Ni-based superalloy and stainless steel coatings, makes iron-aluminum alloys excellent candidates for weld claddings ${ }^{2}$.

Thermal spray coatings have also been considered as protection for boiler tubes in Low NOx furnaces. Thermal spray coatings can be advantageous to weld overlays because they are relatively easy to apply and are not susceptible to cold cracking, unlike weld claddings. Plasma spray coatings have typically been used for corrosion and erosion protection, but they possess oxide inclusions and porosity, which can cause flaking of the coating ${ }^{8}$. Recently, High-velocity Oxy-fuel (HVOF) processes have been used to create dense, low-oxide coatings that contain little porosity 9 . These HVOF 
thermal sprays have outperformed plasma spray coatings during high-temperature corrosion testing ${ }^{10}$. Therefore, HVOF thermal sprays are being considered for coatings as well.

The objectives of this research are: (1) to determine the effects of boiler conditions (i.e. gas composition, slag composition, and temperature) on the corrosion rates of iron-aluminum based weld overlays and HVOF thermal sprays and (2) to determine weld overlay and HVOF thermal spray compositions that can be used as coatings in Low NOx burners. The current research presented in this paper involves preliminary testing of a binary $\mathrm{Fe}-\mathrm{Al}$ alloy in both gaseous and solid-state experiments. The alloy was corroded in four complex gases ranging in $\mathrm{Po}_{2}$ and $\mathrm{Ps}_{2}$ in order to . determine which gases caused the alloy to form non-protective scales. The two environments that produced the least protective scales were chosen for corrosion testing of all alloys selected for this study. The binary $\mathrm{Fe}-\mathrm{Al}$ alloy was also reacted with six types of powered slags. The two powders that produced the thickest reaction scales were chosen for solid-state corrosion testing of all alloys in this study. This paper will identify two gaseous environments and two powders that will be used during future corrosion experiments. A matrix of alloys to be used in these experiments is also identified.

\subsection{EXPERIMENTAL PROCEDURE}

The alloy used for the preliminary gaseous and solid-state testing was Fe10wt\% Al (designated $\mathrm{Fe} 10 \mathrm{Al}$ ). The Fe10Al alloy was cast by arc-melting high purity components under argon and drop casting into a water-cooled copper mold. Cast alloys were used due to results from previous work, which found that high-temperature 
corrosion behavior of weld overlays could be explained using cast alloys of equivalent composition $^{5,11}$. Gaseous corrosion experiments were performed using a Netzsch STA 409 high-temperature thermogravimetric balance, which records weight gain over time. Prior to placing the samples in the balance, the samples were ground to 600 grit with silicon carbide paper and cleaned in ethanol. The sample dimensions were measured to the nearest hundredth of a millimeter, and the samples were weighed to the nearest tenth of a milligram with a digital balance. The samples were heated at a rate of $50^{\circ} \mathrm{C} / \mathrm{min}$ and were isothermally held at $500^{\circ} \mathrm{C}$ for 100 hours. Water was injected into the furnace through capillary tubes attached to a syringe pump. Four types of complex gases were premixed and injected into the furnace at a controlled rate. The types of gases and their components are listed in Table I. The oxygen and sulfur partial pressures were calculated using the HSC Chemistry program and can be seen in Table $\Pi^{12}$. Light Optical Microscopy (LOM) was used to analyze the surface and polished cross-sections of the scales. Scale thickness measurements were made on the polished cross-sections using a light optical microscope and an imaging program.

Fe10Al samples that were used for solid-state experiments were prepared using the same casting process. Samples were ground to 600 grit and cleaned in ethanol prior to being measured and weighed. The sample thickness was measured to the nearest micron and the sample was weighed to the nearest tenth of a milligram using a digital balance. Six powder mixtures (called slags) based on $\mathrm{FeS}$ and $\mathrm{FeS}_{2}$ were selected to simulate slag compositions found on boiler walls. The powder compositions were based on results of field tests from various power generation companies. The powder mixture components were weighed to the nearest tenth of a milligram using a digital scale. The 
components were ball milled for one hour to obtain homogeneous mixtures. The slag compositions prior to milling can be seen in Table III.

The solid-state experiments were conducted using a diffusion couple technique first used by Laheij et. al. ${ }^{13}$. A cylindrical 316L stainless steel reaction vessel was filled halfway with the powder slag and the sample was placed in the center of the vessel. Powder was placed on top of the sample and uniaxial pressure of $300 \mathrm{MPa}$ was applied using 316L stainless steel die plungers. The powder was compressed against the sample and the reaction vessel was sealed (via a tolerance fit) simultaneously during the compression with the die plungers. The entire preparation of the reaction vessel was conducted under a $\mathrm{N}_{2}$ atmosphere to reduce the amount of air present in the vessel. The reaction vessels were then placed into an annealing box, where $\mathrm{N}_{2}$ gas flowed through the box at a constant rate. The annealing box was placed in a furnace and heated to $500^{\circ} \mathrm{C}$ for 450 hours. Light Optical Microscopy (LOM) was used to analyze the surface and polished cross-sections of the scales. Scale thickness measurements were made on the polished cross-sections using a light optical microscope and an imaging program. 
Table I - Gas compositions in volume percent.

\begin{tabular}{|c|c|c|c|c|}
\hline Gas Component & Gas 1 & Gas 2 & Gas 3 & Gas 4 \\
\hline & \multicolumn{3}{|c|}{ Highly Reducing $\longleftarrow$} & Highly Oxidizing \\
\hline $\mathbf{O}_{2}$ & - & -.--..-- & -....-... & 1.0 \\
\hline $\mathrm{CO}$ & 15.0 & 13.1 & 10.2 & 2.1 \\
\hline $\mathrm{CO}_{2}$ & - & 2.0 & 5.1 & 13.5 \\
\hline $\mathrm{H}_{2}$ & 3.3 & 2.5 & -...- & - \\
\hline $\mathrm{H}_{2} \mathrm{~S}$ & 0.12 & 0.12 & 0.12 & 0.06 \\
\hline $\mathrm{SO}_{2}$ & - & - & 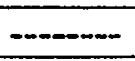 & 0.06 \\
\hline $\mathrm{H}_{2} \mathrm{O}$ & -........ & 0.5 & 2.0 & -...-- \\
\hline $\mathbf{N}_{2}$ & 81.6 & 81.8 & 82.6 & 83.2 \\
\hline
\end{tabular}

Table II - Calculated Oxygen and Sulfur Partial Pressures in atmospheres.

\begin{tabular}{|c|c|c|c|c|}
\hline & Gas 1 & Gas 2 & Gas 3 & Gas 4 \\
\hline Gas Type & Highly Reducing & \multicolumn{3}{c|}{ Highly Oxidizing } \\
\hline $\log \mathbf{P o}_{2}$ & -27.9 & -23.2 & -19.2 & -16.9 \\
\hline $\log \mathbf{P S}_{\mathbf{2}}$ & -6.3 & -3.3 & -8.6 & -13.2 \\
\hline
\end{tabular}

Table III - Slag Compositions in weight percent.

\begin{tabular}{|c|c|c|c|c|c|c|}
\hline Component & Slag 1 & Slag 2 & Slag 3 & Slag 4 & Slag 5 & Slag 6 \\
\hline $\mathrm{FeS}$ & 100 & 50 & 42.5 & $-\cdots$ & $-\cdots$ & $\cdots$ \\
\hline $\mathrm{FeS}_{2}$ & $-\cdots--$ & $-\cdots$ & $-\cdots$ & 100 & 50 & 42.5 \\
\hline $\mathrm{Fe}_{3} \mathrm{O}_{4}$ & $-\cdots$ & 50 & 42.5 & $-\cdots$ & 50 & 42.5 \\
\hline $\mathrm{C}$ & $-\cdots$ & $-\cdots$ & 15 & $\cdots$ & $-\cdots$ & 15 \\
\hline
\end{tabular}

\subsection{RESULTS and DISCUSSION}

\section{Preliminary Gaseous Corrosion Results}

The gaseous corrosion behavior of $\mathrm{Fe} 10 \mathrm{Al}$ was investigated in four gases ranging from highly reducing to oxidizing environments at $500^{\circ} \mathrm{C}$. The weight gain of the alloys in the various environments can be seen in Figure 1. It can be seen from this figure that the alloy exposed to Gas 1 demonstrated almost no weight gain at $500^{\circ} \mathrm{C}$ over 100 hours. 
The LOM micrograph of the reaction product (Figure 2) showed that Fe10Al formed a thin, uniform scale with a thickness of approximately $2 \mu \mathrm{m}$ in this environment.

The corrosion behavior in Gas 2 and Gas 3 seemed to produce similar weight gains and morphologies. Both Gas 2 and 3 exposures produced high weight gains (see Figure 1), which were on the range of $4.3 \mathrm{mg} / \mathrm{cm}^{2}$ over 100 hours. Observations of the scales using LOM helped confirm that similar reactions took place. The scales that formed in Gas 2 and 3 (Figure 3) had very similar morphologies; they both showed a large grained outer layer (light gray), what appeared to be a mixed phase layer (dark gray), and small needles protruding into the substrate. The overall thicknesses of both scales were on the range of $30 \mu \mathrm{m}$, and the thickness of each layer was also similar. Gas 2 had an outer layer thickness of $15.5 \mu \mathrm{m}$ and a mixed inner layer of approximately 15.2 $\mu \mathrm{m}$ in thickness. Whereas, Gas 3 produced an outer layer thickness of $15.4 \mu \mathrm{m}$, while it had a mixed inner layer that was $14.8 \mu \mathrm{m}$ thick. The alloy exposed to Gas 4 demonstrated a low weight gain of less than $1 \mathrm{mg} / \mathrm{cm}^{2}$ over 100 hours. The micrograph seen in Figure 4 shows that the scale consisted of a uniform outer layer (light gray), an inner mixed oxide layer, and a thin uniform inner layer (also light gray). The overall thickness of the scale formed in Gas 4 was relatively thin, as it was measured to be approximately $14.2 \mu \mathrm{m}$ thick.

From these results it can be seen that a protective scale formed during the exposure to Gas 1 . Reactions in Gas 4 produced moderately protective scales, whereas reactions in Gases 2 and 3 resulted in non-protective scales. The two environments that resulted in the worst corrosion behavior were to be selected for future testing. Because Gas 2 and Gas 3 produced very similar scales, only one of these gases were selected for 
future tests. Therefore, Gas 2 and Gas 4 were chosen to use for future corrosion testing of the matrix of alloys and thermal sprays.

\section{Preliminary Solid-State Corrosion Results}

The solid-state corrosion behavior of Fe10Al was investigated in six slag mixtures at $500^{\circ} \mathrm{C}$. The solid-state corrosion behavior was classified in terms of the thickness of the reaction layer that formed during exposure. It could be seen from light optical micrographs that the samples tested with FeS-based slag mixtures demonstrated little to no reaction layer. This can be seen in Figure 5, which shows the reaction layers that formed from exposure to the three FeS-based slags. On the other hand, samples that were tested with $\mathrm{FeS}_{2}$-based slags showed that significant reactions took place. The reaction layers that formed during exposure to $\mathrm{FeS}_{2}$-based slags can be seen in Figure 6. It can be seen from the images shown in Figure 6 that the reaction layers that formed during exposures to $\mathrm{FeS}_{2}$ and $\mathrm{FeS}_{2}+\mathrm{Fe}_{3} \mathrm{O}_{4}+\mathrm{C}$ were considerably thicker than the reaction layer that formed during exposure to $\mathrm{FeS}_{2}+\mathrm{Fe}_{3} \mathrm{O}_{4}$.

The reaction layers shown in Figures 5 and 6 were measured using a light optical microscope and an imaging program. The thickness measurements made on the alloys can be seen in Table IV. The thickness measurements supported the light optical observations. The FeS-based slags produced reaction layers that were difficult to measure because they were under a few microns thick. The standard deviation was larger than the thickness measurements for these samples, so the actual thickness values could not be determined. The reaction layers produced during exposures to $\mathrm{FeS}_{2}$ and $\mathrm{FeS}_{2}+\mathrm{Fe}_{3} \mathrm{O}_{4}+\mathrm{C}$ were approximately $128 \mu \mathrm{m}$ and $127 \mu \mathrm{m}$ thick, respectively. On the other 
hand, the sample reacted with $\mathrm{FeS}_{2}+\mathrm{Fe}_{3} \mathrm{O}_{4}$ showed a reaction layer thickness on the order of $54 \mu \mathrm{m}$.

These thickness measurements show that Fe10Al exposed to FeS-based slags demonstrated little to no reaction during 450 hour exposures at $500^{\circ} \mathrm{C}$. Therefore, the corrosion rate of Fe10Al in FeS-based slags is very low so they would not be good candidate slags for future corrosion testing. Conversely, extensive reactions took place between $\mathrm{Fe} 10 \mathrm{Al}$ and $\mathrm{FeS}_{2}$-based slags. Specifically, the slags that produced the most corrosion product were $\mathrm{FeS}_{2}$ and $\mathrm{FeS}_{2}+\mathrm{Fe}_{3} \mathrm{O}_{4}+\mathrm{C}$. The two slags that produced the thickest reaction layer, $\mathrm{FeS}_{2}$ and $\mathrm{FeS}_{2}+\mathrm{Fe}_{3} \mathrm{O}_{4}+\mathrm{C}$, were chosen for future corrosion testing of the matrix of alloys and thermal spray coatings.

\section{Corrosion of Fe10Al in Gases 1-5 at 500C}

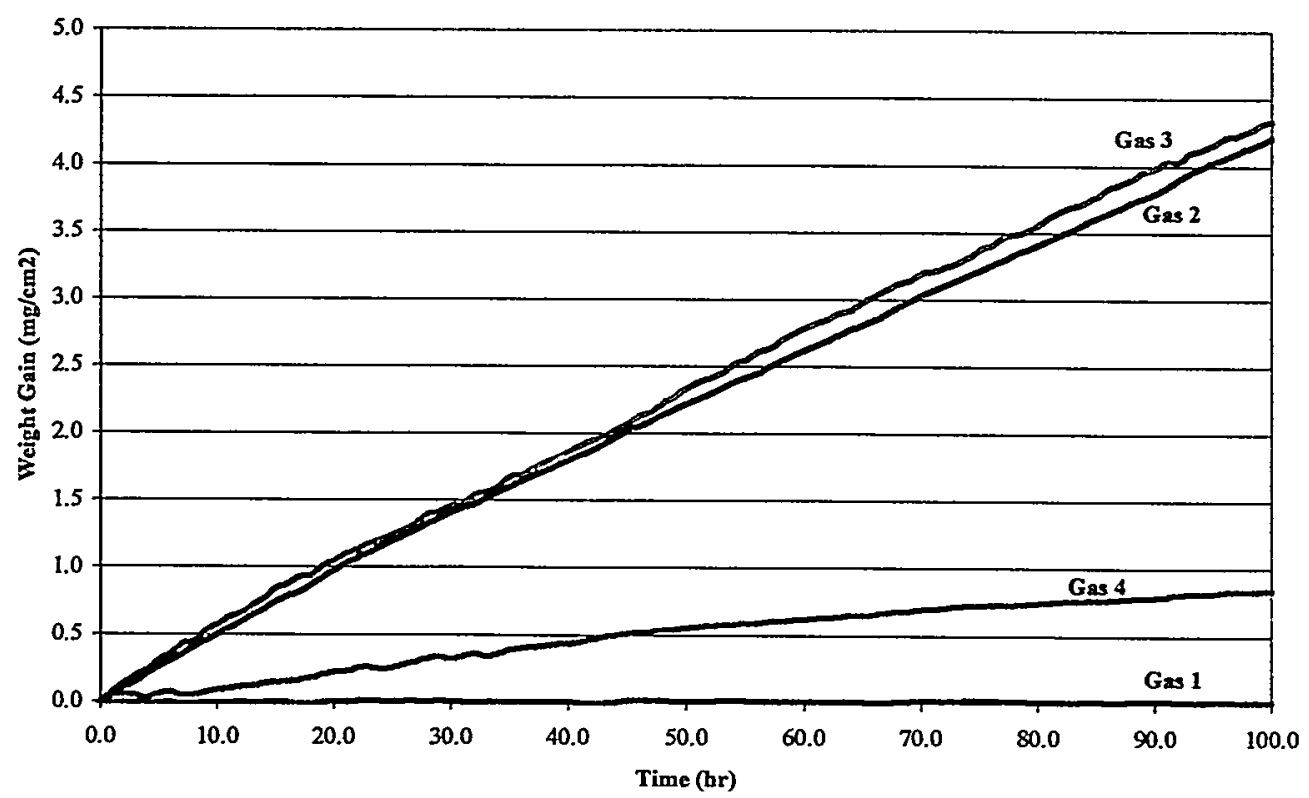

Figure 1 - Weight Gain data for various environments at $500^{\circ} \mathrm{C}$ for 100 hours. 


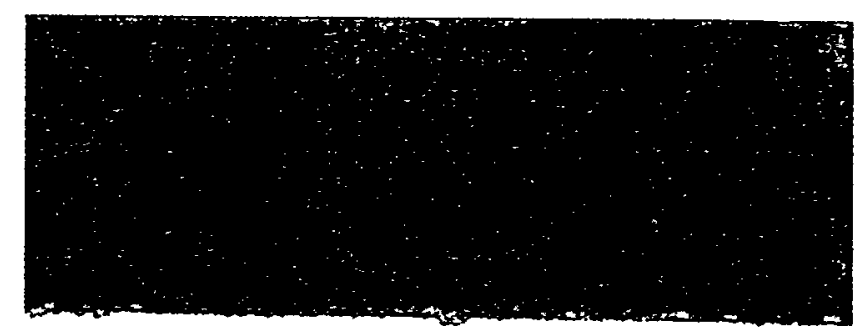

Figure 2-LOM of thin protective scale formed during exposure to Gas 1.
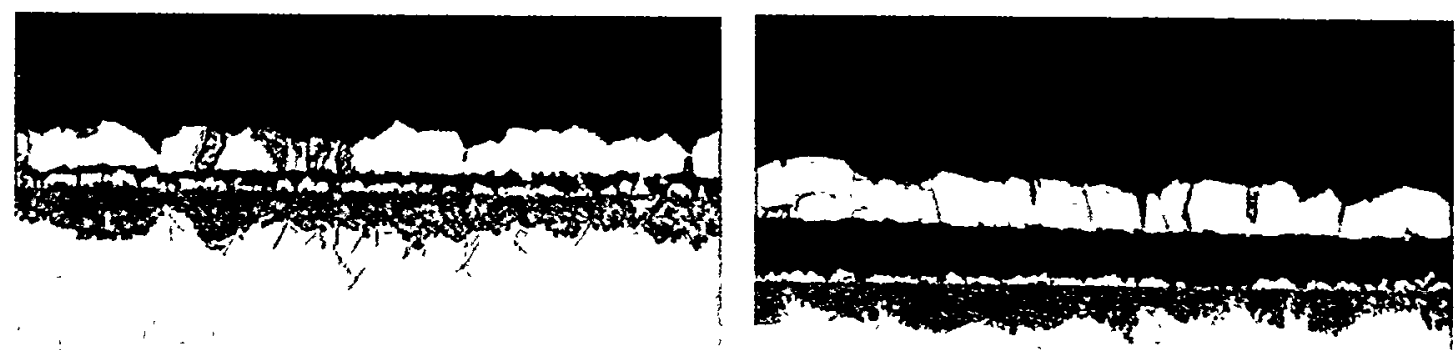

$20 u m$

(a)

$20 \mathrm{um}$

(b)

Figure 3-LOM of scales that formed during exposure to (a) Gas 2 and (b) Gas 3.

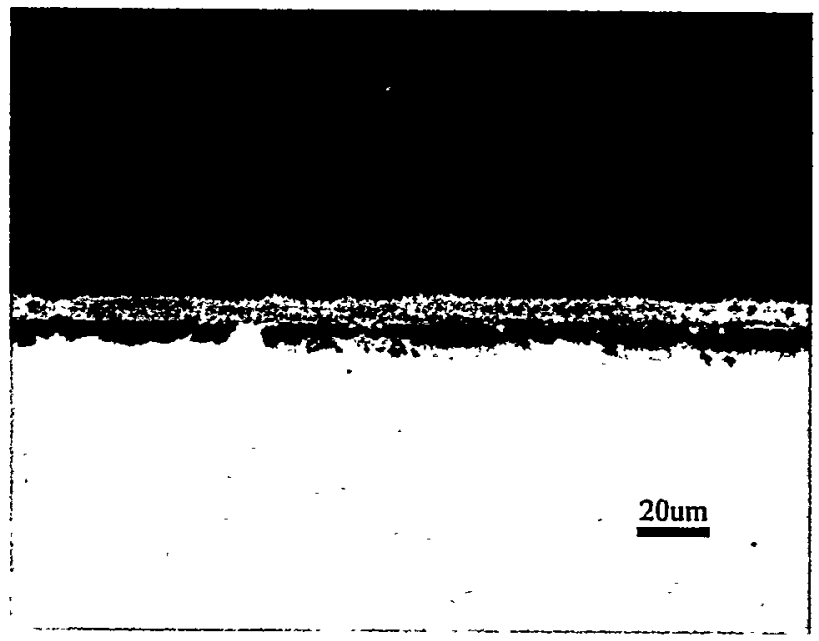

Figure 4-LOM of scale that formed during exposure to Gas 4. 


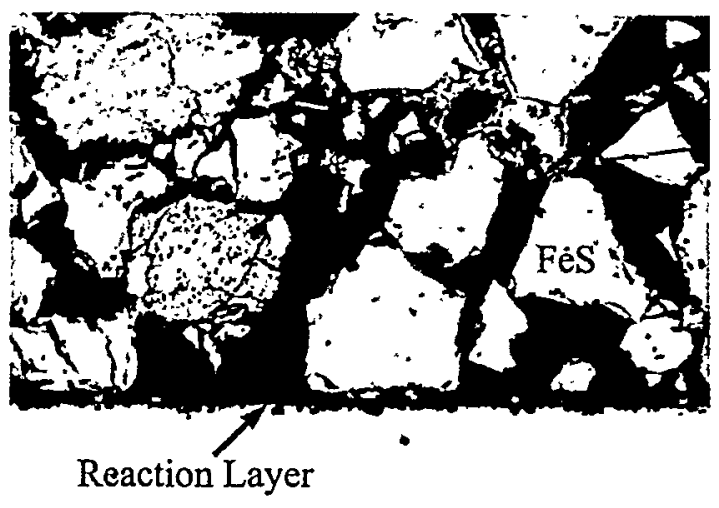

Fe10Al Substrate

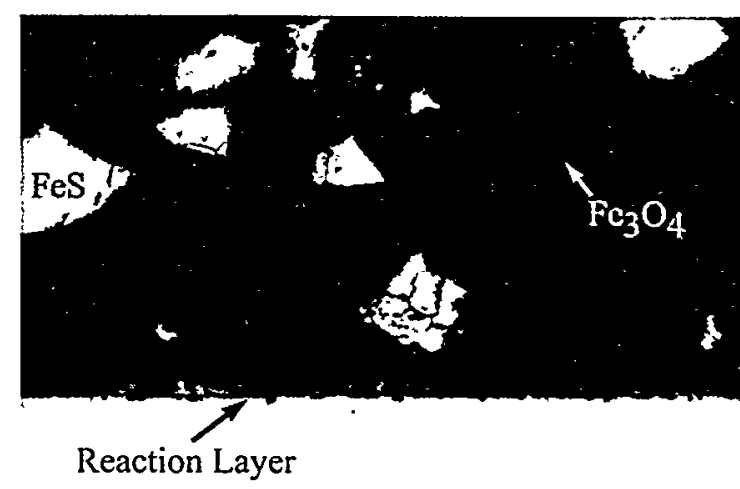

Fe10Al Substrate

$50 \mu \mathrm{m}$

(a)

(b)

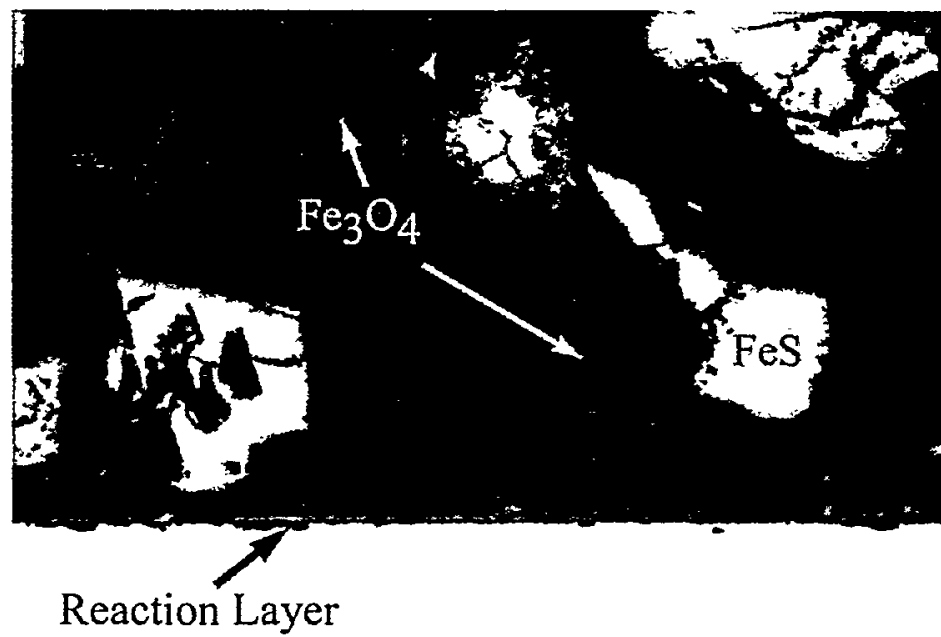

Fe10Al Substrate

$50 \mu \mathrm{m}$

(c)

Figure 5- $\mathrm{LOM}$ of reaction layers after exposure at $500^{\circ} \mathrm{C}$ with (a) $\mathrm{FeS}$, (b) $\mathrm{FeS}+\mathrm{Fe}_{3} \mathrm{O}_{4}$, and (c) $\mathrm{FeS}+\mathrm{Fe}_{3} \mathrm{O}_{4}+\mathrm{C}$. Note that there appears to be little or no reaction layer. 


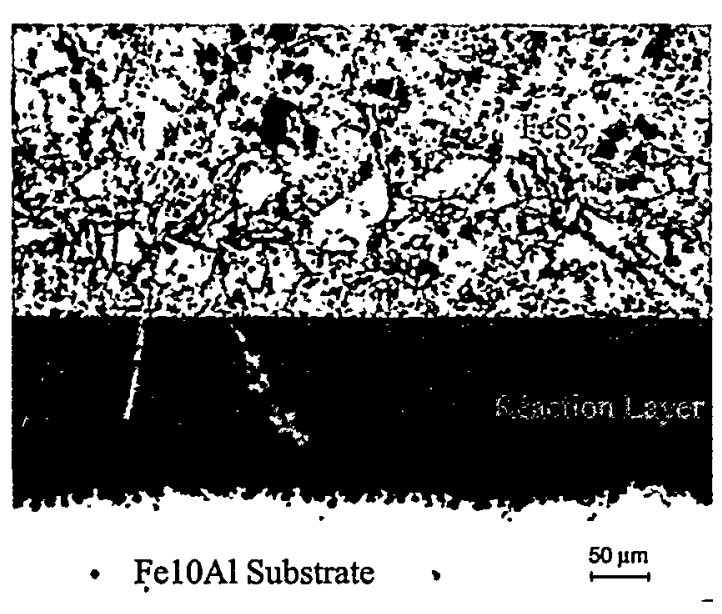

(a)

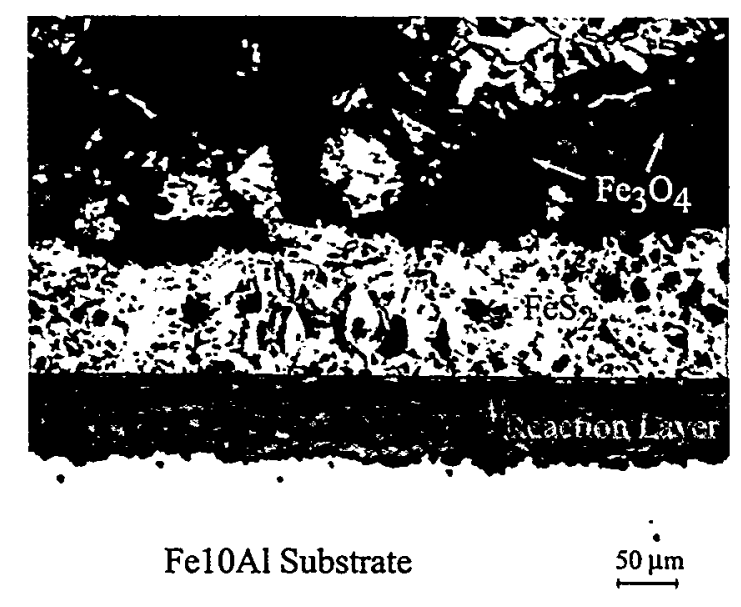

(b)

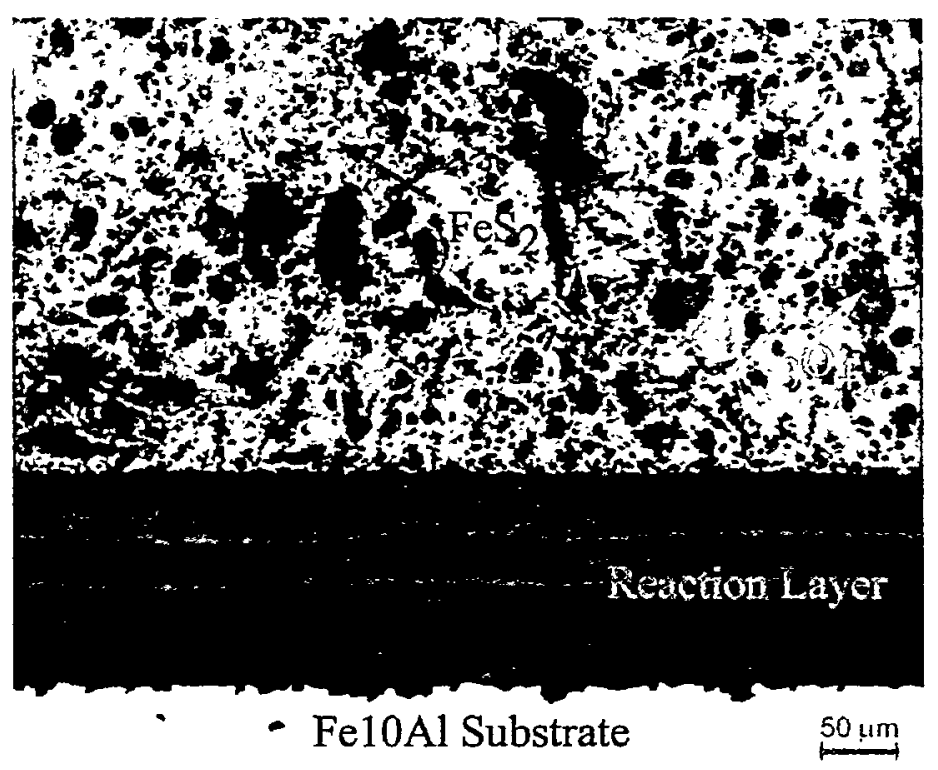

(c)

Figure 6 - LOM of reaction layers after exposure at $500^{\circ} \mathrm{C}$ with (a) $\mathrm{FeS}_{2}$, (b) $\mathrm{FeS}_{2}+\mathrm{Fe}_{3} \mathrm{O}_{4}$, and (c) $\mathrm{FeS}_{2}+\mathrm{Fe}_{3} \mathrm{O}_{4}+\mathrm{C}$ (carbon not shown). Note that the reaction layers in (a) and (b) are significantly thicker than in (c). 
Table IV - Reaction Layer thickness measurements (blue) and the respective standard deviations (red). All measurements are reported in microns. Reactions with FeS-based slags could not be measured because the reaction layer was too thin.

\begin{tabular}{|c|c|}
\hline Slags & $\begin{array}{c}\text { Reaction Layer Thickness } \\
\text { (Standard Deviation) }\end{array}$ \\
\hline $\mathrm{FeS}$ & $-\cdots$ \\
\hline $\mathrm{FeS}+\mathrm{Fe}_{3} \mathrm{O}_{4}$ & ---- \\
& - \\
\hline $\mathrm{FeS}+\mathrm{Fe}_{3} \mathrm{O}_{4}+\mathrm{C}$ & 127.8 \\
\hline $\mathrm{FeS}_{2}$ & 10 \\
\hline $\mathrm{FeS}_{2}+\mathrm{Fe}_{3} \mathrm{O}_{4}$ & 53.9 \\
$\mathrm{FeS}_{2}+\mathrm{Fe}_{3} \mathrm{O}_{4}+\mathrm{C}$ & 5 \\
\hline
\end{tabular}

\subsection{CONCLUSIONS}

The goal of this current phase of the research project was to determine two gaseous environments and two slags that will be used to test various iron-aluminum based alloys and thermal sprays. Fe-10wt\%Al was used for all of the preliminary corrosion testing. The preliminary gaseous corrosion testing was performed in four complex gas environments at $500^{\circ} \mathrm{C}$. Of the four complex gases, the alloy provided the least protection in the two intermediate gases and moderate protection in the oxidizing gas (Gas 4). Because the reactions in the intermediate gases were very similar, Gas 2 and 4 were chosen for future gaseous corrosion tests. Preliminary solid-state testing showed that the three $\mathrm{FeS}$ based slags produced little to no reaction at $500^{\circ} \mathrm{C}$ over 450 hours. On the other hand, the alloys reacted with $\mathrm{FeS}_{2}$ and $\mathrm{FeS}_{2}+\mathrm{Fe}_{3} \mathrm{O}_{4}+\mathrm{C}$ produced the thickest reaction products. These two slags were therefore selected to be used for future corrosion testing. 


\subsection{FUTURE WORK}

Future research will involve extensive gaseous and solid-state corrosion testing of multiple iron-aluminum based alloys and thermal sprays. The alloys to be used in the next phase of this study will contain $7.5-12.5 \mathrm{wt} \% \mathrm{Al}$ with small additions of $\mathrm{Cr}$, $\mathrm{Ti}$, and Si. The alloys are presently being prepared at Oak Ridge National Laboratory (ORNL) and will be characterized and tested when received. The HVOF thermal sprays to be tested will be based on $\mathrm{Fe}-16 \mathrm{wt} \% \mathrm{Al}\left(\mathrm{Fe}_{3} \mathrm{Al}\right)$ and possibly $\mathrm{Fe}-25 \mathrm{wt} \% \mathrm{Al}(\mathrm{FeAl})$. HVOF coating samples based on Fe-16wt\%Al were prepared at Idaho National Engineering and Environmental Laboratory (INEEL) and are presently being characterized. A matrix of the alloys and the HVOF thermal sprays to be used in the next phase of this project can be seen in Table V. Through these corrosion tests, iron-aluminum based weld claddings and HVOF thermal sprays will be identified as coatings for the protection of Low NOx boiler tubes.

Table $\mathbf{V}$ - Matrix of alloys and HVOF thermal sprays to be tested in next phase. All values are in weight percent.

\begin{tabular}{|c|c|c|c|c|c|}
\hline Alloy & $\mathbf{F e}$ & Al & $\mathrm{Cr}$ & Ti & Si \\
\hline 1 & Bal. & 7.5 & 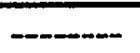 & 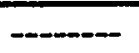 & - \\
\hline 2 & Bal. & 7.5 & 1.0 & -n....... & -...... \\
\hline 3 & Bal. & 7.5 & 2.0 & 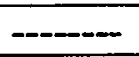 & 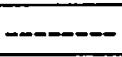 \\
\hline 4 & Bal. & 7.5 & 5.0 & - & - \\
\hline 5 & Bal. & 7.5 & - & 2.0 & 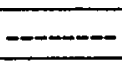 \\
\hline 6 & Bal. & 7.5 & 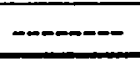 & - & 1.0 \\
\hline 7 & Bal. & 10.0 & 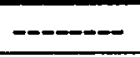 & יו-יביבי & 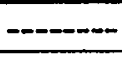 \\
\hline 8 & Bal. & 10.0 & 1.0 & $-\cdots$ & - \\
\hline 9 & Bal. & 10.0 & 2.0 & 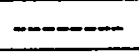 & - \\
\hline 10 & Bal. & 10.0 & 5.0 & - & יב-בי-ב- \\
\hline 11 & Bal. & 10.0 & --.-- & 2.0 & - \\
\hline 12 & Bal. & 10.0 & - & - -...... & 1.0 \\
\hline 13 & Bal. & 12.5 & $-\cdots$ & - -...-- & 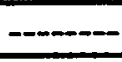 \\
\hline HVOF 1 & Bal. & 16.0 & - & - & 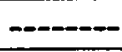 \\
\hline HVOF 2 & Bal. & 25.0 & $\cdots$ & -1 & 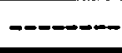 \\
\hline
\end{tabular}




\subsection{REFERENCES}

1. Stringer, J. (1990) In High Temperature Oxidation and Sulphidation Processes, ed. J.D. Embury, Pergamon Press, Toronto, Ontario, pp. 257-76.

2. McKamey, C.G., DeVan, J.H., Tortorelli, P.F., and Sikka, V.K. (1991) J. Mater. Res., Vol. 6, no. 8, pp. 1770-1805.

3. DeVan, J.H. and Tortorelli, P.F. (1993a) Corrosion Science, Vol. 35, no. 5-8, pp. 1065-71.

4. DeVan, J.H. and Tortorelli, P.F. (1993b) Mat. High Temp., Vol. 11, no. 1-4, pp. 30-5.

5. Tortorelli, P.F., DeVan, J.H., Goodwin, G.M., and Howell, M. (1995) In Elevated Temperature Coatings: Science and Technology I, pp. 203-12, Rosemont, IL, Oct 36, TMS, Warrendale, PA.

6. Tortorelli, P.F., Wright, I.G., Goodwin, G.M., and Howell, M. (1996) In Elevated Temperature Coatings: Science and Technology II, pp. 175-85, Anaheim, CA, Feb 48, TMS, Warrendale, PA.

7. Banovic, S.W., DuPont, J.N., and Marder, A.R., (1999) Welding Journal, Vol.78, no.1, pp.23s-30s.

8. Bluni, S.A. and Smith, B.J. (1992) Life Extension of Power Plant Boiler Tubes by Protective Coatings, Energy Research Center Report No. 92-500-1-2. Lehigh University, Bethlehem, PA, 18015.

9. Unpublished Research (1998) Lehigh University, Bethlehem, PA, 18015.

10. Luer, K.R., DuPont, J.N., and Marder, A.R. (2000) Corrosion, Vol. 56, no. 2, pp. 189 98.

11. Tortorelli, P.F., Goodwin, G.M., Howell, M., and DeVan, J.H. (1995) In HeatResistant Materials II, pp. 257-70, TMS, Warrendale, PA.

12. HSC Chemistry for Window, Version 3.0. (1997) Outokumpu Research Oy, Finland, www.outokumpu.fi/hsc.

13. Laheij, M., van Loo, F.J.J., and Metselaar, R. (1980) Oxidation of Metals, Vol. 14, no. 3, pp. 207-15. 
ALLISON GAS TURBINE DIVISION

P.O. Box 420

Indianapolis, IN 46206-0420

P. Khandelwal (Speed Code W-5)

R. A. Wenglarz (Speed Code W-16)

BABCOCK \& WILCOX

Domestic Fossil Operations

20 South Van Buren Avenue

Barberton, OH 44023

M. Gold

BRITISH COAL CORPORATION

Caal Technology Development Division

Stoke Orchard, Cheltenham

Glocestershire, England GL52 4ZG

J. Oakey

CANADA CENTER FOR MINERAL \& ENERGY TECHNOLOGY

568 Booth Street

Ottawa, Ontario

Canada K1A OG1

R. Winston Revie

Mahi Sahoo

COLORADO SCHOOL OF MINES

Department of Metallurgical Engineering

Golden, CO 80401

G. R. Edwards

DOE

DOE OAK RIDGE OPERATIONS

P. O. Box 2008

Building 4500N, MS 6269

Oak Ridge, TN 37831

M. H. Rawlins
DOE

National Energy Technology Laboratory

3610 Collins Ferry Road

P.O. Box 880

Morgantown, WV 26507-0880

D. C. Cicero

F. W. Crouse, Jr.

R. A. Dennis

N. T. Holcombe

W. J. Huber

T. J. McMahon

J. E. Notestein

DOE

National Energy Technology Laboratory 626 Cochrans Mill Road

P.O. Box 10940

Pittsburgh, PA 15236-0940

A. L. Baldwin

G. V. McGurl

U. Rao

L. A. Ruth

T. M. Torkos

DOE

OFFICE OF FOSSIL ENERGY

FE-72

19901 Germantown Road

Germantown, MD 20874-1290

F. M. Glaser

DOE

OFFICE OF BASIC ENERGY SCIENCES

Materials Sciences Division

ER-131 GTN

Washington, DC 20545

H. M. Kerch 
ELECTRIC POWER RESEARCH INSTITUTE

P.O. Box 10412

3412 Hillview Avenue

Palo Alto, CA 94303

W. T. Bakker

J. Stringer

FOSTER WHEELER DEVELOPMENT

CORPORATION

Materials Technology Department

John Blizard Research Center

12 Peach Tree Hill Road

Livingston, NJ 07039

J. L. Blough

IDAHO NATIONAL ENGINEERING

LABORATORY

P.O. Box 1625

Idaho Falls, ID 83415

R. N. Wright

\section{LEHIGH UNIVERSITY}

Materials Science \& Engineering

Whitaker Laboratory

5 E. Packer Avenue

Bethlehem, PA 18015

J. N. DuPont

OAK RIDGE NATIONAL LABORATORY

P.O. BOX 2008

Oak Ridge, TN 37831

M. P. Brady

P. T. Carlson

J. M. Crigger (3 copies)

R. R. Judkins

C. T. Liu

M. L. Santella

J. H. Schneibel

V. K. Sikka

R. W. Swindeman

P. F. Tortorelli

I. G. Wright
PACIFIC NORTHWEST LABORATORY

P. O. Box 999, K3-59

Battelle Boulevard

Richland, WA 99352

R. N. Johnson

THE UNIVERSITY OF LIVERPOOL

Liverpool, United Kingdom

L69 3BX

A. $R$. Jones

THE WELDING INSTTTUTE

Abington Hall, Abington

Cambridge CB1 6AL

United Kingdom

P. L. Threadgill

UNIVERSITY OF CALIFORNIA

AT SAN DIEGO

Department of Applied Mechanics and

Engineering Sciences

La Jolla, CA 92093-0411

B. K. Kad

UNIVERSITY OF TENNESSEE AT KNOXVILLE

Materials Science and Engineering

Department

Knoxville, TN 37996

P. K. Liaw

WEST VIRGINIA UNIVERSITY

Department of Physics

Morgantown, WV 26506-6315

B. R. Cooper 